\title{
Effect of adding nettle plant on some physiological and biochemical parameters of broiler chickens
}

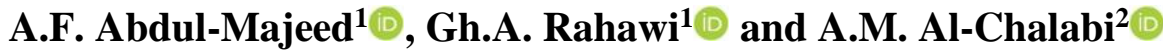 \\ ${ }^{1}$ Department of Animal Production, College of Agriculture and Forestry, University of Mosul, Mosul, ${ }^{2}$ Department of Research \\ and Development, Nineveh Governorate, Iraq
}

\begin{tabular}{l} 
Article information \\
\hline Article history: \\
Received October 09, 2021 \\
Accepted November 09, 2021 \\
Available online December 11, 2021 \\
\hline Keywords: \\
Blood hemoglobin \\
Clotting time \\
Differential leukocyte count \\
Packed cell volume \\
Urtica dioica \\
\hline
\end{tabular}

Correspondence:

A.F. Abdul-Majeed

dr.abdullah@uomosul.edu.iq

\begin{abstract}
The objective of this study is to find out the impact of the nettle plant (Urtica dioica $L$.) on broiler, because of its wide spread in our regions, and insufficient information about its effects on the broiler, as most of the current researches refers its uses in folk medicine. So, this research had been conducted to evaluate the effects of adding 0.25 and $0.5 \%$ crushed nettle/kg diet on the blood picture and some biochemical indices of broiler. 180 broiler chicks (Ross 308), one-day-old were randomly distributed into 3 groups (60 birds/group) with 3 replicates/group ( 20 birds/replicate), and treated until 42 days age as follows: $1^{\text {st }}$ group (Control): standard diets without additives, $2^{\text {nd }}$ group: $0.25 \%$ nettle $/ \mathrm{kg}$ diet, $3^{\text {rd }}$ group: $0.50 \%$ nettle $/ \mathrm{kg}$ diet. Results showed that crushed nettle plant led to an increase in the values of packed cell volume, hemoglobin, mean corpuscular hemoglobin concentration, and it's shortened clotting time, as well as a significant increase $(\mathrm{P} \leq 0.05)$ in the number of basophils compared to the control group. In regard to the biochemical profile in the blood serum of broiler, most of biochemical indices values became better and significant when adding nettle (high-density lipoproteins, low-density lipoproteins, risk index, total protein, globulin, aspartate aminotransferase and alanine aminotransferase). In conclusion, nettle can be given to broiler in these proportions to improve the hematological and biochemical indices due to its properties and contents.
\end{abstract}

DOI: 10.33899/ijvs.2021.131844.2010, (CAuthors, 2021, College of Veterinary Medicine, University of Mosul.

This is an open access article under the CC BY 4.0 license (http://creativecommons.org/licenses/by/4.0/).

\section{Introduction}

Recently, medicinal and aromatic herbal plants and their extracts have received great attention for their health benefits and for their use as growth promoters $(1,2)$. One of these plants which belongs to the Urticaceae family is Nettle (Stinging nettle) (Urtica dioica L.), which is widely cultivated in the world, and it is noted as a herbal plant with medicinal properties (3). Many species of nettle can be found in Iraq, including Urtica dioica and Urtica uren, which are used to improve human and animals' health, because they contain more than 50 different chemical compounds, especially their active and effective antioxidant compounds (4). Studies have indicated the importance of using nettle, especially the vegetative part (leaves), as it was used as a nutritional supplement in poultry feed (5) to enhance the physiological and productive performance of hens (6). Nettle plant has a variety nutrients, including: antioxidants, vitamins (vitamin B complex, A, C, E, and K) $(7,8)$, which are a necessary for the bird's resistance against diseases and stress, hemoglobin formation, and tissue growth (9), as well as being a good source of amino acids which is important in the bird's body growth such as lysine and glutamine and methionine (8).

Also it contains several mineral salts such as calcium, iron, magnesium, cobalt, manganese, phosphorus, potassium and sodium (7). Also, it contains histamine, acetylcholine, serotonin, anticoagulants, formic acid, salicylic acid, thymol and carvacrol $(8,10)$. 
Physiological changes were observed by Hashemi et al. (11) in the values of RBCs and platelets of broiler reared on a ration containing different levels of dried nettles.

\section{Materials and methods}

A total of one hundred eighty broiler chicks (Ross 308), one-day-old were randomly distributed into 3 groups (60 birds/ group), with 3 replicates/group (20 birds/replicate), which were reared on ground pens with dimensions $2.5 \mathrm{x}$ $2.5 \times 3.0 \mathrm{~m}$ for width, length and height respectively, and the requirements of temperature, humidity, ventilation and lighting were taken into consideration according to the bird's age. Dried nettle leaves (Urtica dioica L.) have been bought from the local markets, then it was crushed and mixed with the standard diets. Diet was formed according to the poultry nutrition requirement (12). The diets included: a starter ration till 21days aged $(21.6 \%$ crude protein and $2960 \mathrm{kcal} / \mathrm{kg}$ ), then a grower ration till 42 days aged $(19.3 \%$ crude protein and $3060 \mathrm{kcal} / \mathrm{kg})$. The diets and water were offered ad libitum to all birds till 42 days age, and the groups were as follows: $1^{\text {st }}$ group (Control): birds were reared on a standard diet without additives. $2^{\text {nd }}$ group: birds were reared on a standard diet supplemented by $0.25 \%$ nettle $/ \mathrm{kg}$ diet. $3^{\text {rd }}$ group: birds were reared on a standard diet supplemented by $0.50 \%$ nettle $/ \mathrm{kg}$ diet.

At 42 days age, six birds from each group were slaughtered, and the blood specimens were collected directly at the slaughtering in two types of tubes: tubes containing the EDTA anticoagulant and plain tubes (contains gel and a clot activator). The isolated serum was preserved at $-20^{\circ} \mathrm{C}$ until the hematological tests will be done. Packed cell volume (PCV) were performed according to the technique described in Campbell (13), and blood hemoglobin $(\mathrm{Hb})$ concentration was determined according to the Drabkin's method (14) utilizing Kit (Biosystems, Spain) as mentioned in Abdul-Majeed et al. (15), then the mean corpuscular hemoglobin concentration (MCHC) was calculated as described by Abdul-Majeed and AbdulRahman (16), and as stated in Campbell (13), and the blood clotting time was determined using capillary tube method as described by Pal and Pal (17). Giemsa-stained blood smears for differential leukocyte count (DLC) has been done as stated in Campbell (13).

Also, blood glucose, lipid profiles [total cholesterol, triglyceride, high-density lipoprotein (HDL), low-density lipoproteins (LDL), and very low-density lipoproteins (VLDL)], total protein, albumin, globulin, aspartate aminotransferase (AST) and alanine aminotransferase (ALT) activities were estimated by utilizing kits (Biosystems, Spain).

\section{Statistical analysis}

The analysis of data was performed by using Statistical Analysis Statics program (18), according to the one-way analysis of variance in the Complete Randomized Design (C.R.D). The differences between means were determined by Duncan's multiple range test at the probability level $(\mathrm{P} \leq 0.05)$ according to Steel and Torrie (19).

\section{Results}

As shown in Table 1 there are significant increases $(\mathrm{P} \leq 0.05)$ in the values of $\mathrm{PCV}, \mathrm{Hb}$ and $\mathrm{MCHC}$ in $\mathrm{T}_{2}$ and $\mathrm{T}_{3}$ compared with the control group. While the clotting time has decreased significantly $(\mathrm{P} \leq 0.05)$ in $\mathrm{T}_{3}$ compared with a control group.

Table 2 shows a non-significant difference in differential blood leukocyte count and stress index between the study groups, except for the basophiles which is increased significantly $(\mathrm{P} \leq 0.05)$ in $\mathrm{T}_{2}$ and $\mathrm{T}_{3} 4.00$ and $4.67 \%$ respectively compared with a control group $2.67 \%$.

Table 3 showed that nettle treatment improves significantly the lipid profile as represented by the significant increase in the $\mathrm{HDL}$ in $\mathrm{T}_{3} 56.37 \mathrm{mg} / \mathrm{dl}$ significant decrease in LDL in $\mathrm{T}_{2}$ and $\mathrm{T}_{3} 44.72,46.32 \mathrm{mg} / \mathrm{dl}$ and risk ratio (LDL/HDL) $0.86,0.82$ respectively as compared with control group 49.56, $50.41 \mathrm{mg} / \mathrm{dl}$ and 1.02 for HDL, $\mathrm{LDL}$ and risk ratio respectively at $(\mathrm{P} \leq 0.05)$.

Table 4 , revealed that the addition of nettle significantly increased $(\mathrm{P} \leq 0.05)$ the value of total protein, globulin and globulin/albumin in $\mathrm{T}_{3}$ compared to the control group $(\mathrm{P} \leq 0.05)$, while the blood glucose and albumin levels were not affected.

On the other hand, nettle treatments reduce significantly the AST values 222.23, 223.96 U/L in $\mathrm{T}_{2}$ and $\mathrm{T}_{3}$ respectively as compared with control group $268.18 \mathrm{U} / \mathrm{L}$, and ALT 29.40 U/L in $\mathrm{T}_{3}$ as compared with control and $\mathrm{T}_{2}$ groups 37.24, 36.45 $\mathrm{U} / \mathrm{L}$ respectively (Table 5).

Table 1: Effect of crushed nettle on blood picture and clotting time of broiler at 42 days age (Means \pm SE)

\begin{tabular}{lcccc}
\hline Treatments & $\mathrm{Hb}(\mathrm{g} / \mathrm{dl})$ & $\mathrm{PCV}(\%)$ & MCHC $(\mathrm{g} / \mathrm{dl})$ & Clotting time (second) $^{\mathrm{b}}$ \\
\hline Control & $10.50 \pm 0.33^{\mathrm{b}}$ & $29.67 \pm 0.42^{\mathrm{b}}$ & $35.39 \pm 0.94^{\mathrm{b}}$ & $41.62 \pm 2.50^{\mathrm{a}}$ \\
$0.25 \%$ Nettle $/ \mathrm{kg}$ diet & $11.95 \pm 0.25^{\mathrm{a}}$ & $31.17 \pm 0.60^{\mathrm{a}}$ & $38.38 \pm 0.83^{\mathrm{a}}$ & $34.58 \pm 2.54^{\mathrm{ab}}$ \\
$0.50 \%$ Nettle $/ \mathrm{kg}$ diet & $12.52 \pm 0.10^{\mathrm{a}}$ & $31.50 \pm 0.43^{\mathrm{a}}$ & $39.76 \pm 0.47^{\mathrm{a}}$ & $27.22 \pm 2.65^{\mathrm{b}}$ \\
\hline
\end{tabular}

Different letters in the same column mean a statistical difference at $\mathrm{P} \leq 0.05$. 
Iraqi Journal of Veterinary Sciences, Vol. 35, Supplement III, 2021 (115-119)

Proceedings of the 13th (2nd International) Scientific Conference, College of Veterinary Medicine, University of Baghdad

Table 2: Effect of crushed nettle on differential blood leukocyte count and stress index of broiler at 42 days age (Means \pm SE)

\begin{tabular}{lcccccc}
\hline Treatments & $\begin{array}{c}\text { Heterophils } \\
\%\end{array}$ & $\begin{array}{c}\text { Eosinophils } \\
\%\end{array}$ & $\begin{array}{c}\text { Basophils } \\
\%\end{array}$ & $\begin{array}{c}\text { Lymphocytes } \\
\%\end{array}$ & $\begin{array}{c}\text { Monocytes } \\
\%\end{array}$ & $\begin{array}{c}\text { Stress index } \\
(\mathrm{H} / \mathrm{L} \text { Ratio })\end{array}$ \\
\hline Control & $30.00 \pm 0.52^{\mathrm{a}}$ & $2.00 \pm 0.37^{\mathrm{a}}$ & $2.67 \pm 0.33^{\mathrm{b}}$ & $62.50 \pm 0.56^{\mathrm{a}}$ & $2.83 \pm 0.17^{\mathrm{a}}$ & $0.48 \pm 0.01^{\mathrm{a}}$ \\
$0.25 \%$ Nettle/k diet & $29.67 \pm 0.71^{\mathrm{a}}$ & $2.67 \pm 0.49^{\mathrm{a}}$ & $4.00 \pm 0.37^{\mathrm{a}}$ & $61.17 \pm 1.14^{\mathrm{a}}$ & $2.50 \pm 0.22^{\mathrm{a}}$ & $0.49 \pm 0.02^{\mathrm{a}^{\mathrm{a}}}$ \\
$0.50 \%$ Nettle/k diet & $29.83 \pm 0.83^{\mathrm{a}}$ & $1.83 \pm 0.31^{\mathrm{a}}$ & $4.67 \pm 0.33^{\mathrm{a}}$ & $60.67 \pm 0.56^{\mathrm{a}}$ & $3.00 \pm 0.37^{\mathrm{a}}$ & $0.49 \pm 0.02^{\mathrm{a}}$ \\
\hline
\end{tabular}

Different letters in the same column mean a statistical difference at $\mathrm{P} \leq 0.05$.

Table 3: Effect of crushed nettle on total lipid profile and risk index of broiler at 42 days age (Means \pm SE)

\begin{tabular}{lcccccc}
\hline Treatments & $\begin{array}{c}\text { Cholesterol } \\
(\mathrm{mg} / \mathrm{dl})\end{array}$ & $\begin{array}{c}\text { Triglycerides } \\
(\mathrm{mg} / \mathrm{dl})\end{array}$ & $\begin{array}{c}\text { HDL } \\
(\mathrm{mg} / \mathrm{dl})\end{array}$ & $\begin{array}{c}\text { LDL } \\
(\mathrm{mg} / \mathrm{dl})\end{array}$ & $\begin{array}{c}\text { VLDL } \\
(\mathrm{mg} / \mathrm{dl})\end{array}$ & $\begin{array}{c}\text { Risk Index } \\
(\mathrm{LDL} / \mathrm{HDL})\end{array}$ \\
\hline Control & $110.37 \pm 2.70^{\mathrm{a}}$ & $51.59 \pm 2.52^{\mathrm{a}}$ & $49.56 \pm 1.91^{\mathrm{b}}$ & $50.41 \pm 0.85^{\mathrm{a}}$ & $10.40 \pm 0.50^{\mathrm{a}}$ & $1.02 \pm 0.03^{\mathrm{a}}$ \\
$0.25 \%$ Nettle $/ \mathrm{kg} \mathrm{diet}$ & $106.71 \pm 2.82^{\mathrm{a}}$ & $49.75 \pm 1.01^{\mathrm{a}}$ & $52.03 \pm 1.61^{\mathrm{ab}}$ & $44.72 \pm 1.36^{\mathrm{b}}$ & $9.95 \pm 0.20^{\mathrm{a}}$ & $0.86 \pm 0.02^{\mathrm{b}}$ \\
$0.50 \%$ Nettle/kg diet & $113.59 \pm 2.23^{\mathrm{a}}$ & $54.52 \pm 2.07^{\mathrm{a}}$ & $56.37 \pm 1.48^{\mathrm{a}}$ & $46.32 \pm 0.85^{\mathrm{b}}$ & $10.90 \pm 0.42^{\mathrm{a}}$ & $0.82 \pm 0.01^{\mathrm{b}}$ \\
\hline
\end{tabular}

Different letters in the same column mean a statistical difference at $\mathrm{P} \leq 0.05$.

Table 4: Effect of crushed nettle on blood glucose, total protein, albumin, globulin, and globulin/albumin of broiler at 42 days age (Means \pm SE)

\begin{tabular}{lccccc}
\hline Treatments & $\begin{array}{c}\text { Glucose } \\
(\mathrm{mg} / \mathrm{dl})\end{array}$ & $\begin{array}{c}\text { Total protein } \\
(\mathrm{g} / \mathrm{dl})\end{array}$ & $\begin{array}{c}\text { Albumin } \\
(\mathrm{g} / \mathrm{dl})\end{array}$ & $\begin{array}{c}\text { Globulin } \\
(\mathrm{g} / \mathrm{dl})\end{array}$ & Globulin / Albumin \\
\hline Control & $220.41 \pm 5.34^{\mathrm{a}}$ & $3.36 \pm 0.08^{\mathrm{b}}$ & $1.42 \pm 0.06^{\mathrm{a}}$ & $1.94 \pm 0.09^{\mathrm{b}}$ & $1.38 \pm 0.11^{\mathrm{b}}$ \\
$0.25 \%$ Nettle/kg diet & $215.54 \pm 2.34^{\mathrm{a}}$ & $3.39 \pm 0.13^{\mathrm{b}}$ & $1.20 \pm 0.09^{\mathrm{a}}$ & $2.19 \pm 0.15^{\mathrm{ab}}$ & $1.88 \pm 0.23^{\mathrm{ab}}$ \\
$0.50 \%$ Nettle/kg diet & $224.26 \pm 3.44^{\mathrm{a}}$ & $3.74 \pm 0.07^{\mathrm{a}}$ & $1.25 \pm 0.08^{\mathrm{a}}$ & $2.49 \pm 0.14^{\mathrm{a}}$ & $2.06 \pm 0.25^{\mathrm{a}}$ \\
\hline
\end{tabular}

Different letters in the same column mean a statistical difference at $\mathrm{P} \leq 0.05$.

Table 5: Effect of crushed nettle on blood AST and ALT of broiler at 42 days age (Means \pm SE)

\begin{tabular}{lcc}
\hline Treatments & AST (U/L) & ALT (U/L) \\
\hline Control & $268.18 \pm 4.09^{\mathrm{a}}$ & $37.24 \pm 0.38^{\mathrm{a}}$ \\
$0.25 \%$ Nettle $/ \mathrm{kg}$ diet & $222.23 \pm 2.28^{\mathrm{b}}$ & $36.45 \pm 0.33^{\mathrm{a}}$ \\
$0.50 \%$ Nettle $/ \mathrm{kg} \mathrm{diet}$ & $223.96 \pm 1.77^{\mathrm{b}}$ & $29.40 \pm 0.22^{\mathrm{b}}$ \\
\hline
\end{tabular}

Different letters in the same column mean a statistical difference at $\mathrm{P} \leq 0.05$.

\section{Discussion}

The addition of nettle improved the blood picture, as it significantly increased the values of $\mathrm{PCV}, \mathrm{Hb}$ and $\mathrm{MCHC}$ compared to the control group. These findings agree with the Al-Salihi et al. (5) and Hashemi et al. (11) who said that nettle plant contains several vitamins, minerals (vitamin C, A, E, B complex, iron, copper) $(7,8)$, antioxidants (4) and formic acid, salicylic acid, thymol and carvacrol $(8,10)$, which increases the absorption and metabolism of iron from the gastrointestinal tract, and activates the secretion of the erythropoietin from the kidney, which in turn stimulates the bone marrow to produce red blood cells and then increase the PCV and $\mathrm{Hb}(20)$.

We also observe from Table 1 that the nettle plant led to a reduction in the blood clotting time in the $\mathrm{T}_{3}$ (decrease duration of bleeding) compared to the control group, Nasiri et al. (10) and Mansoub (21) stated that nettle is rich in vitamin K (4), which acts as hemostatic (Antihemorrhagic) (22).

The increase in basophils \% due to nettle treatments, may sustain the previous studies that nettle may have allergic effect due to its histamine content (23).

Nettle treatment with dose used in the current study $(0.25$ and $0.5 \% / \mathrm{kg}$ diet $)$ for 42 days did not subject any stressful effects on the broiler birds as it was clear by the significant reduction in AST and ALT values (Table 5) and the normal stress index values (Table 2).

The improvement in lipid profile of broiler which represented in the significant increase of HDL and the significant reduction of LDL and risk index was in agreement with Hashemi et al. (11) and Keshavarz et al. (24) who suggested that nettle might improve lipoprotein synthesis and metabolism which is reflected in the enhancement of HDL and reduction of LDL and risk index, Righi et al. (25) suggested that the nettle effect on lipid profile maybe related to its high content of antioxidants as polyphenols and vitamins. On the other, the results of the current study on lipid profile not agree with the results of Mansoub (21) and Safamehr et al. (26) in broiler.

The results of nettle treatments on serum glucose were agree with the finding of Safamehr et al. (26), and the 
albumin levels agreed with the finding of Mansoub (21), and Keshavarz et al. (24), and disagreed with finding of AlSalihi et al. (5) who reported that the addition of nettle watery extract to the drinking water of broiler significantly increase albumin level.

Regarding the effects of nettle on total protein, globulin and globulin/albumin, it was agreed with Sharma et al. (27) in its effect on globulin, but did not agree with it in its effect on total protein and globulin / albumin. Dalla and Sheboun (9) reported that nettle was rich in lysine, glutamine and methionine as well as vitamins and many minerals, which may enhance the serum protein levels.

For the impact of nettle treatments on AST and ALT activities, Ozen and Korkmaz (28) reported that this effect may be related to the activation of some antioxidant enzymes as catalase and glutathione transferase, also ELAshmawy et al. (29), Loetscher et al. (30) and Kukric (31) refers that nettle has a high content of vitamin, minerals, isoflavones, and polyphenols which enhance the antioxidant status and reduce the impact of stress on cells.

\section{Conclusions}

We can conclude that nettle did not induce negative impacts when added by 0.25 and $0.5 \%$ on hematological traits, and improved the physiological performance of broiler. However, it needs more studies to validate the effect of nettle, because there are few studies on the effects of this plant on broiler.

\section{Acknowledgments}

The authors would like to thanks the University of Mosul and the College of Agriculture and Forestry for their assistance in this research. Also, we would like to thank Dr. Saeb Younis Abdul-Rahman for his assistance provided on this research.

\section{Conflict of Interest}

The authors declare that there are no conflicts of interest regarding the publication of this manuscript.

\section{References}

1. Khosravi A, Boldaji F, Dastar B, Hasani S. The use of some feed additives as growth promoter in broilers nutrition. Int $\mathbf{J}$ Poult Sci. 2008;7(11):1095-1099. DOI: 10.3923/ijps.2008.1095.1099

2. Mohammed HN. Broiler performance response to anise seed powder supplementation. Iraqi J Vet Sci. 2019;33(1):131-5. DOI: 10.33899/ijvs.2019.125533.1055

3. Viegi L, Pieroni A, Guarrera PM, Vangelisti R. A review of plants used in folk veterinary medicine in Italy as basis for a databank. $\mathrm{J}$ Ethnopharmacol. 2003;89(2-3):221-244.

DOI:
4. Pant V, Sundriyal RC. Nutritional and therapeutic efficacy of stinging nettle - a review. J Ethnobiol Tradit Med. 2016;126:1240-1254. [available at]

5. Al-Salihi AA, Hassan MA, Al-Gharawi JK. Effect of using water extract of nettle leaves (Urtica dioica) on some immunological and blood traits of broiler. J Res Ecol. 2018;6(2):1794-1799. [available at]

6. Milosevic B, Omerovic I, Savic Z, Andjusic L, Milanovic V, Ciric S. Stinging nettle (Urtica dioica) in broiler nutrition. Worlds Poult Sci J. 2021;15:1-2. DOI: 10.1080/00439339.2021.1963645

7. Said AA, Otmani IS, Derfoufi S, Benmoussa A. Highlights on nutritional and therapeutic value of stinging nettle (Urtica dioica). Int J Pharm Pharm Sci. 2015;7(10):8-14. [available at]

8. Pant V. Himalayan Stinging Nettle: Rich Source of Protein and Minerals. J Ethnobiol Tradit Med Photon. 2019;130:1532-1548. DOI: 10.13140/RG.2.2.29576.44801

9. Dalla T, Sheboun A. Evaluation of some medical plants and their extracts as feed additives in broiler diets on health indicators and productive performance. Tishreen Uni J Res Sci Stud Biol Sci Series. 2014;36(4):49-67. https://bit.ly/3bipp2T

10. Nasiri S, Nobakht A, Safamehr A. The effects of different levels of nettle Urtica dioica L. (Urticaceae) medicinal plant in starter and grower feeds on performance, carcass traits, blood biochemical and immunity parameters of broilers. Iran J Appl Anim Sci. 2011;1(3):177-181. [available at]

11. Hashemi SM, Soleimanifar A, Sharifi SD, Vakili N. Growth promoting effects of dried nettle extracts and its impact on hematology and antibody titter in broiler chickens. Int J Anim Sci. 2018;2(2):1016. [available at]

12. National Research Council. Nutrient requirement of poultry. $9^{\text {th }}$ ed. Washington: National Academy Press; 1994. 26-32 p.

13. Campbell TW. Avian hematology and cytology. $2^{\text {nd }}$ ed. Iowa State University Press. 1995;176-198 p.

14. Drabkin DL, Austin JH. Spectrophotometric studies II. Preparations from washed blood cells; nitric oxide hemoglobin and sulfhemoglobin. J Biol Chem. 1935;1;112(1):51-65. [available at]

15. Abdul-Majeed AF, Alkarad HA, Abdul-Rahman SY. Effect of vitamin $\mathrm{C}$ on blood picture and some biochemical parameters of quail stressed by $\mathrm{H}_{2} \mathrm{O}_{2}$. Iraqi J Vet Sci. 2012;26(2):77-82. DOI: 10.33899/ijvs.2012.67445

16. Abdul-Majeed AF, Abdul-Rahman SY. Impact of breed, sex and age on hematological and biochemical parameters of local quail. Iraqi $\mathbf{J}$ Vet Sci. 2021;35(3):459-464. DOI: 10.33899/ijvs.2020.126960.1432

17. Pal GK, Pal P. Textbook of practical physiology. $2^{\text {nd }}$ ed. India: Orient Longman. 2006.108-109 p. [available at]

18. Statistical Analysis Systems. Software, User's Guide: Statistics, V. 9.2, $2^{\text {nd }}$ ed. SAS Institute, Cary, North Carolina, USA; 2008.

19. Steel RGD, Torrie JH. Principles and Procedures of Statistics. NY: McGraw-Hill Book Company; 1960. 207-208 p.

20. Ifeanyi OE. A review on erythropoietin. Int J Adv Res Biol Sci. 2015;2(4):35-47. [available at]

21. Mansoub NH. Comparison of effects of using nettle (Urtica dioica) and probiotic on performance and serum composition of broiler chickens. Glob Vet. 2011;6(3):247-50. [available at]

22. Zeipina S, Alsina I, Lepse L. Stinging nettle-the source of biologically active compounds as sustainable daily diet supplement. Livest Res Rural Dev. 2014;20(1):34-38. [available at]

23. Schapira R, Adams K. Nettle allergy: A review and clinical perspective. Curr Treat Options Allergy. 2018;5(3):310-318. DOI: 10.1007/s40521-018-0178-0

24. Keshavarz M, Rezaeipour V, Asadzadeh S. Growth performance, blood metabolites, antioxidant stability and carcass characteristics of broiler chickens fed diets containing nettle (Urtica dioica. L) powder or essential oil. Int J Adv Biol Biom Res. 2014;2(9):2553-61. [available at]

25. Righi F, Pitino R, Manuelian CL, Simoni M, Quarantelli A, De Marchi M, Tsiplakou E. Plant feed additives as natural alternatives to the use of synthetic antioxidant vitamins on poultry performances, health, and oxidative status: A review of the literature in the last 20 years. Antioxidants. 2021;10(5):659. DOI: 10.3390/antiox10050659 
26. Safamehr A, Mirahmadi M, Nobakht A. Effect of nettle (Urtica dioica) medicinal plant on growth performance, immune responses, and serum biochemical parameters of broiler chickens. Int Res J Appl Basic Sci. 2012;3(4):721-728. [available at]

27. Sharma S, kumar Singh D, Gurung YB, Shrestha SP, Pantha C. Immunomodulatory effect of stinging nettle (Urtica dioica) and Aloe vera (Aloe barbadensis) in broiler chickens. Vet Anim Sci. 2018;6:5663. DOI: $10.1016 /$ j.vas.2018.07.002

28. Ozen $\mathrm{T}$, Korkmaz H. Modulatory effect of Urtica dioica $\mathrm{L}$. (Urticaceae) leaf extract on biotransformation enzyme systems, antioxidant enzymes, lactate dehydrogenase and lipid peroxidation in mice. Phytomed. 2003;10(5):405-415. DOI: 10.1078/0944-711300275

29. EL-Ashmawy IM, EL-Nahas AF, Salama OM. Protective effect of volatile oil, alcoholic and aqueous extract of Origanum majorana on lead acetate toxicity in mice. Basic Clin Pharmacol Toxicol. 2005;97(4):238-243. DOI: 10.1111/j.1742-7843.2005.pto 136.x

30. Loetscher Y, Kreuzer M, Messikommer RE. Utility of nettle (Urtica dioica) inlayer diets as a natural yellow colorant for egg yolk. Anim $\begin{array}{llll}\text { Feed Sci Technol. 2013;186(3-4):158-168. DOI: } & \end{array}$ 10.1016/j.anifeedsci.2013.10.006

31. Kukric ZZ, Topalic-Trivunovic LN, Kukavica BM, Matos SB, Pavicic SS, Boroja MM, Savic AV. Characterization of antioxidant and antimicrobial activities of nettle leaves (Urtica dioica $\mathrm{L}$.). Acta Period Technol. 2012;(43):257-272. DOI: 10.2298/APT1243257K

\section{تأثير إضافة نبات القريص في بعض المعايير

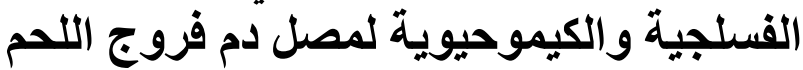

'قسم الإنتاج الحيو اني، كلية الزر اعة و الغابات، جامعة الموصل، گَقسم

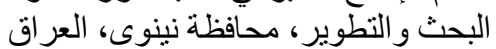

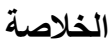

الهدف من هذه الدراسة هو معرفة تأثثر نبات القريص في فروج

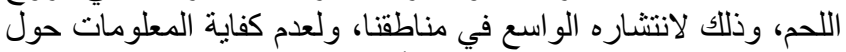

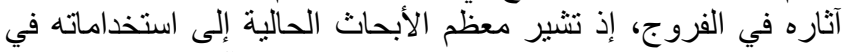

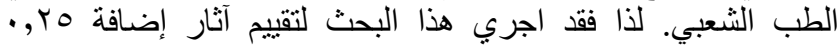

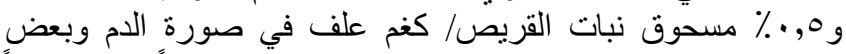

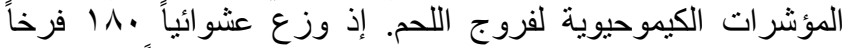

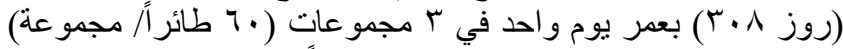

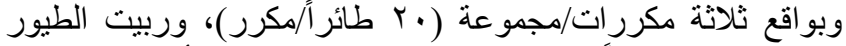

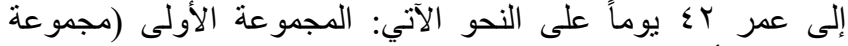

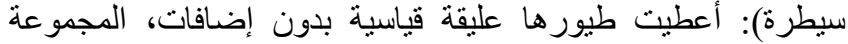

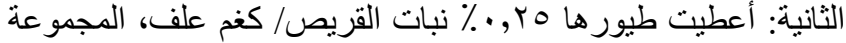

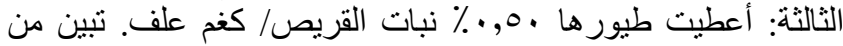

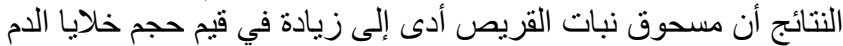

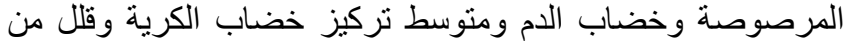

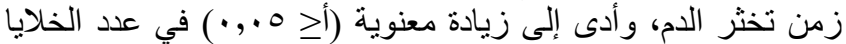

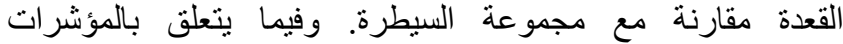

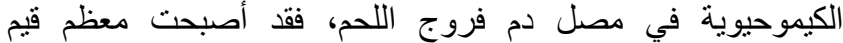

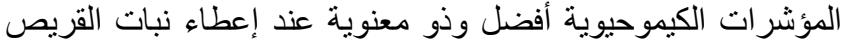
(البروتينات الدهنية عالية الكثافة والبروتينات الدهنية واتية واطنئة الكثافة

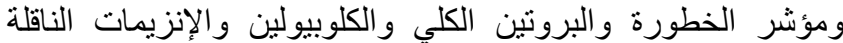

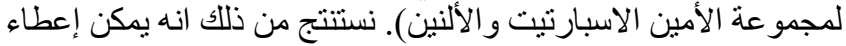

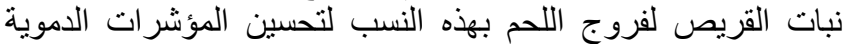
و الكيموحيوية وذلك لخصائصسه ومحتوياته. 